\title{
Viewpoint - Is the race for remote, very large marine protected areas (VLMPAs) taking us down the wrong track?
}

\section{PJS Jones ${ }^{1 *}$ and EM De Santo ${ }^{2}$}

[1] Department of Geography, University College London (UCL), Gower Street, London WC1E 6BT, UK, Tel: +44 (0)207679 0528, p.j.jones@ucl.ac.uk

[2] Department of Earth and Environment, Franklin \& Marshall College, PO Box 3003, Lancaster, PA 17603, USA, Tel: +1 717358 4555, edesanto@fandm.edu

${ }^{*}$ Correspondence Author: P.J.Jones@ucl.ac.uk

\begin{abstract}
This viewpoint article argues that relatively recent increases in the designation of remote, very large marine protected areas (VLMPAs) around the world threatens to undermine the very purpose and objectives of the Aichi biodiversity targets they are aiming to address. Questions are raised about the effectiveness, representativeness, and potential for connectivity of these remote VLMPAs as well as whether they are equitably managed. In addition, it is argued that the push for such designations in countries' overseas territories deflects attention and effort from the challenge of designating and effectively managing MPAs closer to home. In the run-up to the 2016 IUCN World Conservation Congress and Conference of Parties to the Convention on Biological Diversity (CBD), it is important for countries to recognize that remote VLMPAs are but one type of MPA, requiring significant investment in monitoring and enforcement in order to effectively achieve conservation objectives, and that achieving the Aichi MPA coverage target largely through such designations will undermine the aims of this target. To better meet the MPA network criteria set out by the $\mathrm{CBD}$, a range of types of MPAs must be implemented, including smaller MPAs in more intensely used 'metropolitan seas', and social justice considerations must be better integrated in conservation planning. It is important that the race towards remote VLMPAs does not divert attention, resources and political will away from the other types of MPA that are necessary for effectively fulfilling marine conservation targets.
\end{abstract}

\section{Key Words}

Marine protected areas; Aichi target; network design; effectiveness; equity

\section{Highlights}

- MPA coverage targets are leading to an increasing focus on remote very large MPAs.

- The resultant networks will not fulfil several criteria of the Aichi MPA Target.

- Effective, representative, coherence and equity criteria are unlikely to be achieved.

- Smaller partly protected MPAs that are not isolated are also needed.

- MPA networks need to include a diversity of different types of MPA.

This is the authors' version of the final accepted Marine Policy manuscript. Elsevier@ 2016. This manuscript version is made available under the CC-BY-NC-ND 4.0 license. DOI:10.1016/j.marpol.2016.08.015

\section{@creative}

Jones PJS and De Santo EM (2016) Viewpoint - Is the race for remote, very large marine protected areas (VLMPAs) taking us down the wrong track? Marine Policy 73, 231-234 http://dx.doi.org/10.1016/j.marpol.2016.08.015 Elsevier(C 2016. This manuscript version is made available under the CC-BY-NC-ND 4.0 license 
This 'viewpoint' article questions the disproportionate contribution that remote very large marine protected areas (VLMPAs) are making to the achievement of the Aichi 10\% MPA coverage target. It argues that several elements of this target, particularly effectiveness, representativeness, coherence and equity, are unlikely to be met if the majority of the MPA coverage is achieved through such designations. It concludes that the race to designate the largest MPA should not divert attention, resources, and political will from efforts for smaller MPAs that provide for some compatible activities in more intensively used seas. This article is based on the views of the authors and aims to provide a contribution to debates on MPA coverage targets, particularly in relation to the upcoming IUCN World Conservation Congress (September 2016) and Thirteenth Conference of the Parties to the Convention on Biological Diversity (December 2016).Targets for marine conservation have been prominent since 1998, when 1605 scientists from around the world signed a call for governments to protect $20 \%$ of the world's seas from all threats by 2020. More recently, in 2011, 271 scientists called for the designation of a worldwide system of very large no-take marine protected areas (MPAs) as 'an essential and long overdue contribution to improving stewardship of the global oceanic environment' [1 at $p$. 7]. There have also been several policy targets for MPA coverage, ranging from informal calls through the IUCN World Parks Congress and World Conservation Congress, to more binding targets through the UN World Summit on Sustainable Development and the Convention on Biological Diversity. The latter's 2010 Aichi Target 11 calls for at least $10 \%$ of the world's seas to be effectively conserved through systems of MPAs by 2020 . The achievement of such targets has increasingly been implemented through the designation of very large marine protected areas (VLMPAs) on the scale of hundreds of thousands of square kilometres, often surrounding islands in remote oceans. Some of these areas encompass the entire Exclusive Economic Zone (EEZ) of island nations (e.g. Palau), while others comprise the EEZ surrounding an overseas territory of countries with such holdings (e.g. USA, UK, France). The first modern (i.e. $21^{\text {st }}$ Century) remote VLMPA was the $340,000 \mathrm{~km}^{2}$ Northwestern Hawaiian Islands Coral Reef Ecosystem Reserve, designated in 2000, as part of President Clinton's departing environmental legacy, and larger than all of America's national parks combined. This remote VLMPA was later included in the Papahānaumokuākea Marine National Monument (MNM), the 2006 designation by President Bush building on the previous one. Initially open to bottom trawling, all fishing throughout the PMNM was banned in 2011, as whilst 'bigger is better', it is also considered that 'no-take is best'. The race was on.

There have since been many more designations in the race to declare the largest MPA in the world and add to the list of 'flagship' remote VLMPAs (see table below). Every time there is a new 'leader' in the size stakes, it is feted in the media, giving the impression of a competitive edge. This race has been enthusiastically supported by conservation campaign groups and donors, and many governments have joined in, all keen to gain the green credentials associated with remote VLMPAs. This has led to $~ 62 \%$ of global MPA coverage being down to just 24 such designations (all $>100,000 \mathrm{~km}^{2}$ ) amongst a total of over 6,000 MPAs, which all together cover only $3.27 \%$ of the global marine area [2], so without remote VLMPAs, the $10 \%$ target would be even further from being reached. In addition, some of these areas have been expanded since their designation, for example the US expanded the Pacific Remote Islands MNM in 2014, and did the same with Papahānaumokuākea in August 2016, more than quadrupling its size [3] and making it the leader in the race for the world's largest MPA.

A recent paper on the effectiveness of MPAs [4] provides scientific evidence to support this race, as it found that there are five key features of MPAs that promote the effective achievement of conservation outcomes being large, well enforced, no-take, old and isolated from fished areas. However, a related paper [5] argues that MPAs are increasingly biased towards such isolated areas that are residual to commercial use and therefore have not yet been heavily exploited. The remoteness of such isolated residual areas means that they can often be closed with relatively few political costs, as they tend to be in overseas territories where few, if any, mainland voters live, and with relatively minor economic costs, as commercial exploiters tend to be incoming fishing vessels from other countries. Indeed, it has also been suggested that larger MPAs are more

Jones PJS and De Santo EM (2016) Viewpoint - Is the race for remote, very large marine protected areas (VLMPAs) taking us down the wrong track? Marine Policy 73, 231-234 http://dx.doi.org/10.1016/j.marpol.2016.08.015 Elsevier(C) 2016. This manuscript version is made available under the CC-BY-NC-ND 4.0 license 
cost-effective to implement and manage than their smaller counterparts [6]. This is, however, contingent upon their having a sufficient enforcement capacity to be ecologically effective, and the actual cost of effective enforcement for remote VLMPAs has yet to be determined.

Table 1: Remote Very Large MPAs designated since 2000 (from De Santo, 2013 [7], updated with data from WDPA and MPAtlas.org). Asterix $(*)$ beside date indicates VLMPA has been proposed but not yet designated.

\begin{tabular}{|c|c|c|}
\hline Date & Remote VLMPA Name, Country & Size $(\mathbf{k m 2})$ \\
\hline 2006 & Papahānaumokuākea Marine National Monument (MNM), USA & $\begin{array}{l}\text { Expanded to } 362,075, \\
\text { made } 100 \% \text { no-take in } \\
2011 \text { and expanded to } \\
1,508,870 \text { in } 2016\end{array}$ \\
\hline 2008 & Phoenix Islands Protected Area (PIPA), Kiribati & 408,250 \\
\hline 2009 & Marianas Trench MNM, USA & 248,517 \\
\hline 2009 & $\begin{array}{l}\text { Pacific Remote Islands MNM, USA (Wake Island, Howard and Baker } \\
\text { Islands, Johnston Atoll, Palmyra Atoll/Kingman Reef, and Jarvis } \\
\text { Island) }\end{array}$ & $\begin{array}{l}225,039-\text { expanded to } \\
1,277,860 \text { in } 2014\end{array}$ \\
\hline 2009 & Rose Atoll MNM, USA & 35,001 \\
\hline 2009 & Prince Edward Islands MPA, South Africa & 181,229 \\
\hline 2009 & South Orkneys MPA, UK/Argentina & 92,819 (100\% no-take) \\
\hline 2010* & $\begin{array}{l}\text { Chagos British Indian Ocean Territory, UK (rendered legally invalid } \\
\text { by UN Permanent Court of Arbitration in 2015) }\end{array}$ & 640,000 (100\% no-take) \\
\hline 2010 & Motu Motiro Hiva Marine Park, Chile & 150,000 \\
\hline 2010 & Charlie Gibbs North High Seas MPA, OSPAR & 177,700 \\
\hline 2010 & Charlie Gibbs South High Seas MPA, OSPAR & 145,420 \\
\hline 2012 & Marae Moana, Cook Islands Marine Park & $1,065,000$ \\
\hline $2012^{*}$ & Coral Sea Commonwealth Marine Reserve, Australia & 989,842 \\
\hline 2012 & South Georgia and South Sandwich Islands MPA & $1,070,000$ \\
\hline 2014 & Natural Park of the Coral Sea (New Caledonia), France & $1,368,806$ \\
\hline $2015 *$ & Easter Island Marine Park, Chile & $\begin{array}{l}720,017 \text { (69\% no-take, } \\
496,570)\end{array}$ \\
\hline $2015^{*}$ & Pitcairn Island, UK & 836,064 (100\% no-take) \\
\hline 2015 & Kermadec Ocean Sanctuary, New Zealand & 620,000 (100\% no-take) \\
\hline 2015 & Palau National Marine Sanctuary & 500,000 \\
\hline 2015 & Nazca Desventuradas, Chile & 297,518 (100\% no-take) \\
\hline $2016^{*}$ & Ascension Island, UK & 234,291 (50\% no-take) \\
\hline
\end{tabular}

From the perspective of national governments, it is clear that remote VLMPAs are win-win, in that they gain green credentials and contribute to each country's progress towards the Aichi target. Why go through the politically and economically expensive process of designating relatively small MPAs around the mainland when you can designate remote VLMPAs in overseas territories with minimal costs and many gains? From the perspective of conservation campaigners and donors, it is clear that remote VLMPAs deliver high profile benefits, in that they safeguard large areas of relatively pristine seas from increasingly pervasive fishing industry pressures. The persuasiveness of such rationales is evident in the increasing number of remote VLMPAs and proportion of global MPA coverage that they represent. Some of these areas are now sharing

Jones PJS and De Santo EM (2016) Viewpoint - Is the race for remote, very large marine protected areas (VLMPAs) taking us down the wrong track? Marine Policy 73, 231-234 http://dx.doi.org/10.1016/j.marpol.2016.08.015 Elsevier@ 2016. This manuscript version is made available under the CC-BY-NC-ND 4.0 license 
lessons/expertise for designing and managing VLMPAs, e.g. the Big Ocean network, connecting the Cook Islands Marine Park, Great Barrier Reef Marine Park, Papahānaumokuākea MNM, Phoenix Islands Protected Area, Mariana Trench MNM, Chagos/British Indian Ocean MPA and Motu Motiro Hiva. The area encompassed in this association is enormous, 3.2 million square kilometres, twice the size of the Gulf of Mexico, and has made a significant contribution to meeting global MPA targets. Toonen et al. [8] estimate the effort will bring forward the expected date of reaching $10 \%$ by close to thirty years (i.e. 2025 rather than 2054). They also forecast that approximately 54 additional large-scale MPAs (at the mean size of Big Ocean sites) need to be designated in order to reach the Aichi targets.

There are several major problems with this trend towards increasing remote VLMPA coverage, as the Aichi target is about much more than total coverage:

At least $17 \%$ of terrestrial and inland water, and 10\% of coastal and marine areas, especially areas of particular importance for biodiversity and ecosystem services, are conserved through effectively and equitably managed, ecologically representative and well connected systems of protected areas and other effective area-based conservation measures, and integrated into the wider landscape and seascape [by 2020] $-10^{\text {th }}$ Conference of the Parties (COP10) to the Convention on Biological Diversity (CBD), Aichi, Japan, 2010.

The target states that MPAs must be effective in enforcing restrictions on impacting activities, particularly fishing, but vastness and remoteness pose major enforcement challenges. Whilst emerging satellite surveillance technology can help detect illegal fishing vessels, there are still challenges in detaining such vessels through interception by a fisheries patrol vessel, which are very expensive to operate in such vast distant areas, or remotely gaining enough evidence to secure a guilty verdict in court. In some cases, NGOs have been providing funding and logistical support for enforcement (e.g. the Sea Shepherd Society in the Galapagos, and the US-based Marine Conservation Institute in the Pacific [7]). However, detection alone is not enough, vessels must be detained, sufficient evidence gathered, successful prosecutions gained and penalties applied that are sufficient to deter other fishers [1 at p. 154-155]. Given the large areas covered in highly productive regions, several existing VLMPAs contain high concentrations of fish, making them more attractive to illegal, unreported and unregulated (IUU) fishing [9]. It is also worth noting that the pace at which remote VLMPAs are being designated exceeds the pace at which enforcement capacity is being developed, and that some remote VLMPAs are at risk of being 'paper parks' that provide only an illusion of marine conservation.

This concern is driving satellite-based approaches, such as the 'Eyes in the Sky' technology included with the proposal for an MPA surrounding the Pitcairn Islands, supported by the Bertarelli Foundation, Pew Environment Group, and a UK satellite company [10], noting that this proposed reserve is nearly as large as the UK's entire mainland EEZ. This satellite-based approach to enforcement is part of 'Project Eyes on the Seas' to develop and apply remote sensing technology to improve fisheries enforcement around the world, including within remote VLMPAs, and the 'Global Fishing Watch' initiative [11] is taking a similar approach. The recent entry into force of the FAO Port State Measures Agreement [12] has the potential to further support such enforcement by promoting international cooperation to prosecute fishing vessels that have been remotely detected to have been fishing illegally, including in remote VLMPAs, and to block access to landing ports and fish markets. Whilst these recent developments are encouraging with regards to the potential to improve enforcement capacity for remote VLMPAs, the development and implementation of sufficient detection, detainment and deterrence capacity to ensure that such designations are effectively enforced remains a major challenge.

The Aichi target also specifies that MPA systems must be representative, in that they should protect typical examples of species and habitats in each of the world's marine ecoregions, and well connected, in that the MPAs should be close enough together to enable ecological processes to connect between them. $A$ focus on

Jones PJS and De Santo EM (2016) Viewpoint - Is the race for remote, very large marine protected areas (VLMPAs) taking us down the wrong track? Marine Policy 73, 231-234 http://dx.doi.org/10.1016/j.marpol.2016.08.015 Elsevier(C) 2016. This manuscript version is made available under the CC-BY-NC-ND 4.0 license 
relatively few remote VLMPAs in remote and residual areas will not achieve such representative and well connected networks across the world's 232 ecoregions, as MPA coverage will remain patchy and the gaps too large, i.e. MPAs will be separated by large expanses of unprotected ocean. Whilst inshore 'metropolitan' seas near large human populations with a higher number of users represent a challenge, such seas need to be included in MPA networks if they are to be representative and well connected. It could also be argued that whilst such MPAs may have to be smaller and only partly protected in order to provide for fishing activities on which people depend for their protein and livelihoods, perhaps including small no-take zones, it is important to also focus conservation efforts on areas that are under pressure and on which people rely. Marine conservation should be as much about promoting sustainable use in metropolitan seas as it is about promoting no use in remote, residual seas. This is particularly important given that a recent analysis shows that $58 \%$ of the world's coral reefs are within 30 minutes travelling time of the nearest human settlement [13], i.e. more than half the world's corals could be considered as 'metropolitan' and could be neglected if the focus is on remote, very large, no-take MPAs.

Last, but certainly not least, the Aichi target states that MPA networks should be equitably managed, in that the costs and benefits of MPAs should be fairly distributed. Whilst remote VLMPAs tend to be in areas where only a relatively small number of people live, such people do tend to have a high dependence on marine resources, including for commercial and traditional customary use, so it could be unfair to close most or all of the exclusive economic zone to all extractive activities. Such people may be politically remote but their rights must not be marginalised by remote VLMPAs. De Santo [7] sets out the evolution of the $10 \%$ biodiversity target for MPAs, showing linkages to social justice aspects of environmental sustainability set out in the Millennium Development Goals. Arguably these have been lost in the more contemporary time-driven push for MPA targets, as evidenced by the rush to designate the Chagos MPA whilst the European Court of Human Rights was deliberating the future of the native Chagossian people who had been displaced from the area, enabling the US and UK to keep it a de facto militarized zone $[14,15]$.

Consequently, the race to designate MPAs that are very large and remote could be slowing progress towards achieving the Aichi target for effective, representative, well-connected and equitable networks of MPAs, or even taking us down the wrong track. The 10\% MPA coverage target was not achieved by 2012 so the new target is to achieve $10 \%$ coverage by 2020 , though coverage is currently only at around $3 \%$. Nevertheless, the IUCN is likely to continue to push for even larger coverage at its next World Conservation Congress in 2016, with a motion for $30 \%$ of the world's oceans to be completely protected by 2030 , building on a similar recommendation from the World Parks Congress in 2015. In addition, national MPA coverage figures are inflated by designations in countries' overseas territories. For example, the Marine Reserves Coalition's calculation of MPA coverage shows the UK at a high percentage as it includes the Chagos MPA [16]. In reality, the UK's own continental shelf faces many pressures and is highly impacted, with relatively low MPA coverage. A more recent estimate of no-take, highly protected MPA coverage within the territories of $\mathrm{G} 20$ countries [17] takes the same approach, resulting in the United States, UK, and South Africa topping the list (with 13.5\%, 22\% and $4.5 \%$, respectively). Without including remote VLMPAs, only Australia and Saudi Arabia protect more than $1 \%$ of their marine territories in highly protected no-take MPAs, while the United States, UK, and South Africa all drop to less than $1 \%$ [17].

It is clear that in the same way that MPAs need to conserve a diversity of species, MPA networks need to include a diversity of different types of MPA, including remote VLMPAs, but also including smaller MPAs in metropolitan seas that promote sustainable use. Whilst proponents of remote VLMPAs acknowledge that these sites may have fewer conservation benefits if they are designated in residual seas that support relatively low levels of human use $[5,9]$, the reality is that the majority of progress towards achieving the Aichi target has been through such designations. It is important that the race towards remote VLMPAs does not divert

Jones PJS and De Santo EM (2016) Viewpoint - Is the race for remote, very large marine protected areas (VLMPAs) taking us down the wrong track? Marine Policy 73, 231-234 http://dx.doi.org/10.1016/j.marpol.2016.08.015 Elsevier(C) 2016. This manuscript version is made available under the CC-BY-NC-ND 4.0 license 
attention, resources and political will away from the other types of MPA that are necessary for actually fulfilling marine conservation targets.

\section{References}

[1] P.J.S. Jones, Governing marine protected areas: resilience through diversity. Earthscan/Routledge, Oxon, 2014. http://tinyurl.com/GoverningMPAs

[2] L. Boonzaier, D. Pauly, Marine protection targets: an updated assessment of global progress. Oryx 50 (2016) 27-35. http://dx.doi.org/10.1017/S0030605315000848

[3] The White House, Office of the Press Secretary, Fact Sheet: President Obama to Create the World's Largest Marine Protected Area. https://www.whitehouse.gov/the-press-office/2016/08/26/fact-sheet-presidentobama-create-worlds-largest-marine-protected-area

[4] G.J. Edgar, R.D. Stuart-Smith, T.J. Willis, S. Kininmonth, S.C. Baker, S. Banks, N.S. Barrett, M.A. Becerro, A.T.F. Bernard, J. Berkhout, C.D. Buxton, S.J. Campbell, A.T. Cooper, M. Davey, S.C. Edgar, G. Försterra, D.E. Galván, A.J. Irigoyen, D.J. Kushner, R. Moura, P.E. Parnell, N.T. Shears, G. Soler, E.M.A. Strain, R.J. Thomson, Global conservation outcomes depend on marine protected areas with five key features. Nature 506 (2014) 216-220. http://dx.doi.org/10.1038/nature13022

[5] R. Devillers, R.L. Pressey, A. Grech, J.N. Kittinger, G.J. Edgar, T. Ward, R. Watson, Reinventing residual reserves in the sea: are we favouring ease of establishment over need for protection? Aquatic Conservation 25 (2015) 480-504. http://dx.doi.org/10.1002/aqc.2445

[6] A. McCrea-Strub, D. Zeller, U.R. Sumaila, J. Nelson, A. Balmford, D. Pauly, Understanding the cost of establishing marine protected areas. Marine Policy $35 \quad$ (2011) 1-9. http://dx.doi.org/10.1016/j.marpol.2010.07.001

[7] E.M. De Santo, Missing marine protected area (MPA) targets: How the push for quantity over quality undermines sustainability and social justice. Journal of Environmental Management 124 (2013) 137-146. http://dx.doi.org/10.1016/j.jenvman.2013.01.033

[8] R.J. Toonen, T.A. Wilhelm, S.M. Maxwell, D. Wagner, B.W. Bowen, C.R.C. Sheppard, S.M. Taei, T. Teroko, R. Moffitt, C.F. Gaymer, L. Morgan, N. Lewis, A.L.S. Sheppard, J. Parks, A. M. Friedlander, The Big Ocean Think Tank, One size does not fit all. Marine Pollution Bulletin 77 (2013), 7-10. http://dx.doi.org/10.1016/j.marpolbul.2013.10.039

[9] T.A. Wilhelm TA, C.R.C. Sheppard, A.L.S. Sheppard, C.F. Gaymer, J. Parks, D. Wagner, N. Lewis, Large marine protected areas - advantages and challenges of going big. Aquatic Conservation 24(S2) (2014) 24-30. http://dx.doi.org/10.1002/aqc.2499

[10] A. Wilkinson A, UK wants eyes in the sky to keep watch on its record marine reserve. Science website (2015):http://www.sciencemag.org/news/2015/03/uk-wants-eyes-sky-keep-watch-its-record-marinereserve

[11] MPA News, Building the future of MPA enforcement: Project Eyes on the Seas and other high-tech surveillance programs, 17(4), April-May 2016, 1-2. https://mpanews.openchannels.org/news/mpanews/building-future-mpa-enforcement-project-eyes-seas-and-other-high-tech-surveillance

Jones PJS and De Santo EM (2016) Viewpoint - Is the race for remote, very large marine protected areas (VLMPAs) taking us down the wrong track? Marine Policy 73, 231-234 http://dx.doi.org/10.1016/j.marpol.2016.08.015 Elsevier@ 2016. This manuscript version is made available under the CC-BY-NC-ND 4.0 license 
[12] FAO, Port State Measures Agreement (FAO Agreement on Port State Measures to Prevent, Deter, and Eliminate Illegal, Unreported, and Unregulated Fishing), 2009. http://www.fao.org/fishery/psm/agreement/en

[13] E. Maire, J. Conner, L. Velez, C. Huchery, C. Mora, S. Dagata, L. Vigliola, L. Wantiez, M. Kulbicki, D. Mouillot, How accessible are coral reefs to people? A global assessment based on travel time. Ecology Letters 19 (2016) 351-360. http://dx.doi.org/10.1111/ele.12577

[14] E.M. De Santo, P.J.S. Jones, A.M. Miller, Fortress conservation at sea: A commentary on the Chagos marine protected area. Marine Policy 35 (2011) 258-260. http://dx.doi.org/10.1016/j.marpol.2010.09.004

[15] E.M. De Santo, P.J.S Jones, Wikileaked cable on Chagos MPA reveals "fortress" conservation mindset. Letter to the Editor, MPA News, Volume 12 Number 4, (2011). http://depts.washington.edu/mpanews/MPA118.pdf

[16] Marine Reserves Coalition, Marine Protected Area (MPA) League Table of Nations, 2012. http://www.marinereservescoalition.org/files/2012/07/Marine_Reserves_Coalition_MPA_League_Table_Ju ne2012.pdf

[17] K.L.P. Shugart-Schmidt, E.P. Pike, R.A. Moffitt, V.R. Saccomanno, S.A. Magier L.E. Morgan, SeaStates G20 2014: How much of the seas are G20 nations really protecting? Ocean \& Coastal Management 115 (2015) 2530. http://dx.doi.org/10.1016/j.ocecoaman.2015.05.020

Jones PJS and De Santo EM (2016) Viewpoint - Is the race for remote, very large marine protected areas (VLMPAs) taking us down the wrong track? Marine Policy 73, 231-234 http://dx.doi.org/10.1016/j.marpol.2016.08.015 Elsevier(C 2016. This manuscript version is made available under the CC-BY-NC-ND 4.0 license 